\title{
BRONGEBRUIK IN DIE POPULÊRE HISTORIESE ROMAN, MET SPESIALE VERWYSING NA ENGELA VAN ROOYEN EN OSWALD PIROW
}

\author{
Nerine Bosman \\ Departement Afrikaans, Universiteit van Pretoria, 0002
}

\section{Use of sources for popular historical novels, with special reference to Engela van Rooyen and Oswald Pirow}

This paper focuses on the influence that an almost unknown Afrikaans novel, Mlungu Mungoma by Oswald Pirow, (published in 1949) had on aspects regarding characterisation and plot in the popular historical novel Vuur op die horison by Engela van Rooyen (2000). The connection between these two novels and the questions that are raised concerning certain characteristics of the historical novel-more specifically the popular historical novel as opposed to clearly postmodern novels - is investigated. The principal problem statement is the following: in what way or ways do authors of popular historical novels (and in this instance Van Rooyen in particular) give recognition to and admit indebtedness to a text or texts that were used as sources either as sources of inspiration (which is the case here) or for the historical presentation of the novel? Questions that the author addresses are the following:

- What is the nature of the historical novel - how can it be characterised and distinguished from other kinds of fiction?

- Does the popular novel show an awareness of the complex relation between historiography and fiction?

- $\quad$ Is there an existing convention regarding the use and recognition of sources in the (late twentieth, early twenty first century) popular historical novel?

The author argues that the delicate balance between text and source should perhaps be admitted by authors of popular novels, even though the self-conscious way in which postmodern fiction approaches this relationship is absent from typical popular fiction discourse.

Key words: Engela van Rooyen, fiction, historiography, Oswald Pirow, popular historical novel, sources and referencing 
In die artikel word gekonsentreer op die invloed wat uitgeoefen is deur die haas onbekende roman Mlungu Mungoma deur Oswald Pirow (in 1949 gepubliseer) op die historiese roman Vuur op die horison deur Engela van Rooyen (2000). As sentrale vraagstelling geld die volgende: hoe doen outeurs van historiese romans (en hier Van Rooyen in die besonder) verantwoording van en betuig hulle hulle skatpligtigheid teenoor tekste wat as bronne in die roman gedien het - òf as inspirasiebron (wat hier die geval blyk te wees) òf ter wille van die waarheidsgetroue historiese inkleding van die roman? Vrae wat gestel word, is die volgende:

- Wat is die aard van die historiese roman - hoe kan dit getipeer en van ander fiksie afgegrens word?

- Word die verhouding tussen geskiedskrywing en fiksie in die populêre historiese roman geproblematiseer?

- Is daar sprake van 'n konvensie rakende brongebruik en -erkenning in die (laattwintigste-eeuse, vroeg-een-en-twintigste-eeuse) historiese roman?

Die onderskeid tussen historiografie en fiksie word kortliks bespreek voordat die twee romans vergelyk word. Laastens toon die outeur aan dat die delikate balans tussen teks en bronteks miskien duideliker aangedui kan word deur outeurs van populêre historiese fiksie, selfs al word dié saak nie op die selfbewuste wyse as in postmodernistiese fiksie gehanteer nie.

Sleutelwoorde: bronerkenning, brongebruik, Engela van Rooyen, fiksie, geskiedskrywing, Oswald Pirow, populêre historiese roman

\section{Inleiding}

In 1949 verskyn Mlungu Mungoma of Die blanke waarsêer van Oswald Pirow, ${ }^{1}$ 'n teks wat (ook) as historiese roman gekarakteriseer kan word. Volgens alle aanduidings ${ }^{2}$ is dit ' $n$ roman wat lank reeds in die vergetelheid verdwyn het en so sou dit waarskynlik ook gebly het, was dit nie vir 'n ander historiese roman wat in 2000 verskyn nie, $\mathrm{nl}$. Vuur op die horison van Engela van Rooyen. ${ }^{3}$ Die verband tussen hierdie twee romans en die vrae wat dit laat ontstaan oor bepaalde eienskappe van die historiese (en meer spesifiek die sogenaamde populêre historiese) roman en brongebruik (daarmee saam die verhouding tussen "waarheid" en fiksie in die historiese roman), was die primêre

O. Pirow, Mlungu Mungoma of Die blanke waarsêer (Johannesburg, 1949).

Navrae by kollegas en ander lesers het die aanvanklike vermoede bevestig dat Pirow as skrywer, en hierdie roman van hom in die besonder, nie by die hedendaagse leserspubliek bekend is nie.

E. van Rooyen, Vuur op die horison (Kaapstad, 2000). 
aanleiding tot die huidige ondersoek. Vir 'n lekeleser is dié vrae nie bloot interessant nie, maar waarskynlik ook belangrik in die lig van polemieke oor plagiaat wat van tyd tot tyd in die Suid-Afrikaanse pers woed. 'n Verdere aanleiding om die artikel te skryf - en hierin lê die kultuurhistoriese waarde van die ondersoek - was om Pirow se bydrae tot die folkloristiese literatuur in Afrikaans weer onder die aandag van die leserspubliek te bring.

Die sentrale uitgangspunt is 'n ondersoek na die wyse waarop Van Rooyen in Vuur op die horison van Mlungu Mungoma as belangrike inspirasiebron vir een van die karakters in haar roman gebruik gemaak het. Vrae wat met die ondersoek na vore gekom het, was die volgende:

- Wat is die aard van die historiese roman - hoe kan dit getipeer en van ander fiksie afgegrens word?

- Word die verhouding tussen geskiedskrywing en fiksie in die populêre historiese roman geproblematiseer?

- Is daar sprake van 'n konvensie met brongebruik en -erkenning in die (laattwintigste-eeuse, vroeg-een-en-twintigste-eeuse) historiese roman?

Geen poging is aangewend om enigeen van die bogenoemde vrae afdoende of finaal te beantwoord nie. Hulle word wel binne die groter akademiese gesprek aan die orde gestel en kan as beginpunt vir 'n omvattender ondersoek na brongebruik in die historiese roman dien.

Die artikel is soos volg gestruktureer: na 'n bekendstelling van die skrywers Engela van Rooyen en Oswald Pirow en 'n verwysing na hulle oeuvres, word kortliks by die problematiek oor geskiedskrywing en fiksie stilgestaan. Omdat hierdie debat nie die doel van die ondersoek is nie, word die onderwerp baie kursories behandel. Omdat die noukeurige aanduiding al dan nie van bronne waarop gesteun word, enersyds in die brandpunt staan (by name in die postmoderne roman), maar andersyds deur nóg die leser nóg die outeur op die voorgrond geplaas word in die sogenaamde populêre roman, is dit nodig om kortliks na die diskoers rakende historiografie/fiksie te verwys. Die relevansie hiervan word aangedui vir die manier waarop sowel Van Rooyen as Pirow hulle "bronne" hanteer. Ten slotte word gewys op die wyse waarop Van Rooyen van Mlungu Mungoma in haar roman Vuur op die horison gebruik gemaak het.

\section{Oswald Pirow (1890-1959)}

Oswald Pirow, regsgeleerde en politikus, was 'n man van universele talente en belangstellings, briljant op sport- en intellektuele gebied. Tydens sy studie in Engeland wen hy die Inns of Courtbeurs vir jurisprudensie en was hy ook die Britse 
kampioenspiesgooier. Luidens die Standard Encyclopedia of Southern Africa VIII, ${ }^{4}$ was hy hierbenewens ook 'n goeie stoeier, bokser en swemmer, hardloper, boogskutter, internasionale ringgooispeler en vreeslose perderuiter. Hy kwalifiseer as advokaat, betree later die politiek en in 1929 volg hy minister Tielman Roos as Minister van Justisie in die Hertzogkabinet op. In 1957 word hy die leier van die staat se advokatespan in die groot hoogverraadsaak. Pirow was 'n begeesterde grootwildjagter en laastens ook skrywer. Uit sy pen het verskyn Piet Potlood (1948), Mlungu Mungoma of Die blanke waarsêer (1949), Sjangani (1950), Sikororo (1952), Ashambeni (1955) (in Engels) en sy grootste werk, 'n biografie van J.B.M. Hertzog. ${ }^{5}$

In die groot Afrikaanse literatuurgeskiedenisse kom baie min verwysings na hom voor. Kannemeyer ${ }^{6}$ plaas hom in 'n hoofstuk wat handel oor "Dier, inboorling en folklore in die verhaalkuns" en het die volgende oor hom te sê nadat 'n aantal ander skrywers opgenoem is:

Van groter belang is die geskrifte van OSWALD PIROW, wat (...) in Sjangani (1950) ' $n$ fyn beeld van die wedervaringe van 'n klein inboorlingseun gee en in Sikororo (1952) mites, legendes en sprokies van die Bantoe op enigsins amorfe wyse in 'n groter verhaalverband oorvertel.'

Ook Antonissen staan 'n sin of wat aan Pirow af en maak melding van Pirow se insig in die primitiewe denkwêreld van die Afrikamens. ${ }^{8}$ In Perspektief en profiel (1998) word Pirow se naam genoem saam met ander skrywers wat 'n "folkloristiese aanslag" gehad het. ${ }^{9}$

In die inleiding tot Sjangani ${ }^{10}$ skets Pirow kortliks die geskiedenis van die Transvaalse en Portugese Laeveld en maak hy melding van "een van die skilderagtigste figure wat Suidelike Afrika nog opgelewer het" - Joao Albasini (1813-1888). Die skrywer vestig hom hier as 'n kenner van die geskiedenis van die Laeveld en van Sjangaangebruike. Die verhaal van Sjangani ('n soort “swart oemfaan") is dié van 'n jong swart seuntjie wat in die veld rondswerf en op sy eie moet oorleef nadat sy hele stam uitgewis is deur die Zoeloemoordbendes wat in dié tyd 'n skrikbewind in die Laeveld gevoer het. Sy swerftog eindig wanneer jagters van sy oom Mashakatsi (een

\footnotetext{
D.J. Potgieter (et al.), Standard Encyclopedia of Southern Africa (Cape Town, 1973).

O. Pirow, James Barry Munnik Hertzog (Kaapstad, n.d.)

J. Kannemeyer, Geskiedenis van die Afrikaanse literatuur (Kaapstad, 1978).

J. Kannemeyer, Geskiedenis van die Afrikaanse literatuur (1978), p. 352.

R. Antonissen, Die Afrikaanse letterkunde van aanvang tot hede (3de uitgawe) (Kaapstad, 1965),

p. 307.

9 H. van Coller (red.), Perspektief en profiel: 'n Afrikaanse literatuurgeskiedenis (Pretoria, 1998),

p. 43.

10 O. Pirow, Sjangani (Johannesburg, 1950).
} 
van Albasini se krygshere) hom vind. Dit is 'n sjarmante en boeiende avontuurverhaal van oorlewing en vernuf, vol dierestories en met talle verwysings na die leef- en spirituele wêreld van die Sjangaan. Geen verwysing na of vergelyking met 'n Europese wêreld kom daarin voor nie - die verhaal word uitsluitlik uit die oogpunt van die Sjangaanseuntjie vertel. Die enigste aanduiding wat die leser vind dat die skrywer daarvan bewus is dat hy vir oningeligte ("blanke") lesers skryf, is die vertaling tussen hakies van die talle Sjangaanwoorde wat gebruik word, soos hubo, (dorpsplein), nhanga, (gemeenskapshut van die meisies), bandhla (die mans se vergaderplek), psikwembu, (die voorvaders), inoyi, (heks), mungoma (die hoogste graad van toordokter), ens.

Sikororo (Avonture in die Spookland van die Bantu) ${ }^{11}$ is 'n werk wat moeilik toeganklik is. Dit word aangebied as “... 'n verhaal waarin die skrywer probeer het om lewe te blaas in die gelowe, godsdienstige gebruike en opvattinge en ander geestelike kultuur besittings (sic) van die Bantoe", volgens die Voorwoord deur P.J. Coertze. Die skrywer self verwys in sy Inleiding na 'n aantal bronne waarvan hy gebruik gemaak het, maar ook na die feit dat sy speelmaats, tot en met sy negende jaar, feitlik uitsluitlik "Bantoetjies" (sic) was. Soos in sy ander werke, doen hy moeite om die leser te oortuig van die geloofwaardigheid van dit wat aangebied word. Hy maak gebruik van die figuur van Sikororo, 'n karakter wat ook in Mlungu Mungoma aangetref word. Die leser kry te doen met tokkelossie-avonture, verhale van onderwatermense, toordery, reise tot by Kilimandjaro, hekse, vyfkoppige slange, olifantkatte, sneeumannetjies en dergelike meer. Die vertelwyse is nogtans sodanig dat die leser gou hulpeloos verdwaal voel te midde van die magdom vreemde verskynsels. Wat Pirow wel in hierdie drietal boeke reggekry het, was om die leser van die eiesoortige geesteswêreld van die Sjangaan bewus te maak; 'n wêreld wat nêrens elders in die Afrikaanse literatuur so aan ons voorgestel word nie.

Soos Sjangani, is Ashambeni (in Engels geskryf) 'n versameling avontuur- en jagverhale, met 'n voorwoord deur Pirow se vriend, J. Stevenson-Hamilton (parkopsigter van die Nasionale Krugerwildtuin). ${ }^{12}$ Die verhaal speel af in dieselfde tydperk as Sjangani, ongeveer 1850, toe die Zoeloegeneraal Manukosi (of Soshangane, c. 1790-1858) van Shaka (c. 1787-1828) weggebreek het en met die onderwerping van al die swart stamme in Gazaland (Portugees-Oos-Afrika) begin het. Manukosi se skrikbewind het gestrek tot by Lourenço Marques (nou Maputo), Mosambiek, wat hy afgebrand het.

\footnotetext{
11 O. Pirow, Sikororo (Avonture in die Spookland van die Bantu) (Johannesburg, 1952).

12 O. Pirow, Ashambeni (Johannesburg, s.d.).
} 
Ashambeni skets die verhaal en avonture van die groot hond van Mashakatsi. (Dié hond, en Mashakatsi, sy baas, verskyn ook in Sjangani.) Die ontmoeting tussen hond en baas en die daaropvolgende avonture word weergegee. Ook in dié boekie is verwysings na Albasini (Jiwawa), die "wit koning van die knopneuse" en die verbintenis tussen Mashakatsi en die kleurvolle Albasini. Mashakatsi, die jong Sjangaanhoof, word een van Albasini se hoofindoenas, en luidens die verhaal het hy sy mense geleer hoe om met assegaai en skild te veg.

Die boek bestaan hoofsaaklik uit jagverhale - hoe die Sjangaans, met die hulp van Ashambeni, daarin slaag om buffels en ander diere met slegs assegaaie as wapens te jag. In die proses word 'n groot aantal feite omtrent die wildlewe aangebied. As 'n mens iets in die Suid-Afrikaanse verhaleskat soek waarmee hierdie jagverhale vergelyk kan word, is Percy Fitzpatrick se Jock of the Bushveld ${ }^{13}$ die teks waaraan die eerste gedink word. Fitzpatrick se boek het in 1907 die eerste keer verskyn en het sedertdien herhaalde herdrukke beleef.

Wat Pirow gedoen het in die reeks van drie, vier boeke wat nou by mekaar aansluit, is om 'n noukeurige weergawe te gee van aspekte van die geskiedenis van die Sjangaans, en ook om hulle folklore en (by)gelowe in groot detail te beskryf. Die boeke wemel van "figure" soos die baloyi (soort weerwolwe), die psikwembu (voorvadergeeste) en toordokters. In hierdie boekstawing, en nie in enige letterkundige grootheid nie, lê die waarde van sy fiktiewe werk.

Met sy verhale oor die "spookland van die Bantu" staan Pirow dus binne die folkloristiese tradisie in Afrikaans. Trekke van hierdie folkloristiese tematiek tref ons ook aan in Mlungu Mungoma of Die blanke waarsêer (1949), maar in hierdie roman sluit hy ook aan by 'n ander sterk tradisie in Afrikaans, naamlik dié van die historiese roman.

\section{Engela van Rooyen}

Engela Linde is op 11 Augustus 1939 gebore te Kakamas. Haar ouers was pionierkoloniste in 'n besproeiingsnedersetting van die NG Kerk aan die Oranjerivier. Sy behaal haar B.A.-graad aan Stellenbosch en die grade B.A. Honneurs en M.A. aan die Potchefstroomse Universiteit vir Christelike Hoër Onderwys. Name waaronder sy skryf sluit in Engela Linde, Louisa du Toit, Barend Bornman en Engela van Rooyen. Sy skryf radioverhale, jeugverhale en romans. Haar honderste boek, Vuur op die horison, verskyn in 2001. Van haar werk sluit in Die wenteltrap (1970), Kontrapunt (1973), Vollermaan (1982), In die oog van die web (1991) en die jeugherinneringe

13 P. Fitzpatrick, Jock of the Bushveld (London, 1949). 
Met 'n eie siekspens (1994). Vir die jeugverhaal Vuvuzela (2005) is die Sanlamprys vir Jeuglektuur aan haar toegeken. ${ }^{14}$

\section{Die (populêre) historiese roman en die illusie van waarheid: geskiedskrywing en fiksie}

Binne die romankuns en die letterkundige kritiek is dit 'n erkende konvensie om die genre "historiese roman" af te baken en te onderskei van andersoortige romans. Waaroor dit in die eerste plek handel wanneer 'n roman as "histories" getipeer word, is die tydruimtelike plasing van die romangebeure binne 'n herkenbare historiese tydperk (byvoorbeeld die tyd van die Franse Revolusie, die vroeë Kaapse tyd, die tyd van die Groot Trek en die Anglo-Boereoorlog). Die historiese roman put sy verhaalstof uit historiese gebeurtenisse ${ }^{15}$ en plaas fiktiewe karakters in verifieerbare historiese omstandighede. ${ }^{16}$ In Afrikaans is die genre van vroeg af goed bekend. In 1898 reeds verskyn S.J. du Toit se roman Di Koningin fan Skeba. Sonder om 'n volledige lys te verskaf, kan die volgende historiese romans in Afrikaans as voorbeelde genoem word: die Geknelde Land-reeks wat van 1960 tot 1968 verskyn van F.A. Venter, Babette (1995), Catharina (1996) en Charlotta (1999) van Jeanette Ferreira, Op soek na Generaal Mannetjies Mentz (1998) van Christoffel Coetzee, Eilande (2002) van Dan Sleigh en Niggie (2002) van Ingrid Gouws. Ook die jeuglektuur ken hierdie genre - byvoorbeeld die Lafras Cuyper-reeks van Karl Kielblock wat in die jare veertig van die vorige eeu verskyn en Ruiter in die nag van Mikro (1937). Vir die oplettende leser behoort dit uit dié kort lysie duidelik te wees dat 'n verdere onderskeid getref kan word, naamlik tussen die meer populêre historiese roman en literatuur wat duidelik tot die bellettrie hoort. Die klem val in hierdie artikel op twee romans wat eerder in die kategorie "populêr" as "ernstig" sal val.

Dit is noodsaaklik om nog 'n onderskeid, naamlik dié tussen dokumentêre geskiedskrywing en fiksie, van nader toe te lig wanneer die historiese roman as genre beskou word. In die negentiende eeu, waarin dié genre 'n bloeitydperk beleef het, het die historiese roman daarin geslaag om die geskiedenis vir die gewone leser te ontsluit op 'n wyse waartoe die geskiedskrywer nie in staat was nie, onder meer deur gebruik te maak van allerlei stilistiese stylgrepe om die roman van die onaantreklike, saai geskiedskrywing van dié tyd te onderskei. ${ }^{17}$ Bekend met hierdie konvensie, aanvaar

\footnotetext{
14 http://www.storiewerf.co.za, 2009-03-30.

15 H. van Gorp (et al.), Lexicon van literaire termen: stromingen en genres, theoretische begrippen, rhetorische procedes en stijlfiguren (Groningen, 1991).

16 T.T. Cloete (red.), Literêre terme en teorieë (Pretoria, 1992), p. 129.

17 E. Wesseling, Writing history as a prophet (Amsterdam, 1991), p. 33.
} 
die hedendaagse leser van die historiese roman die literêre vormgewing, die versiering, die groter aandag vir die detail van die alledaagse, as part en deel van die genre. Die fiktiwiteit van baie, waarskynlik selfs die meeste, van die verhaalgebeure in die fiktiewe teks is 'n sine qua non van die genre en die leser aanvaar dat die personasies, buiten dié wat herkenbare figure uit die geskiedenis is, waarskynlik ook uit die pen van die skrywer kom. Teenoor die groter vryheid wat die skrywers van historiese romans geniet het, is in dieselfde tydperk (die negentiende eeu) nog sterk op die wetenskaplike status van geskiedskrywing aanspraak gemaak. 'n "(A)andrang op juiste feite, objektiwiteit en verfynde tegnieke met betrekking tot bronondersoek" kenmerk byvoorbeeld die geskiedskrywing sedert die negentiende eeu tot en met ongeveer die vyftigerjare van die vorige eeu. ${ }^{18}$

Vandag, minstens in soverre dit die akademiese gesprek betref, word die onderskeid tussen historiografie en letterkunde of fiksie veel genuanseerder hanteer. Van die tweede helfte van die twintigste eeu word die sogenaamde korrekte weergawe van feite wat in die historiografie aangetref sou word, in twyfel getrek en die ooreenkomste uitgelig wat tussen die roman en geskiedskrywing op narratologiese vlak bestaan. In sy ontleding van die historiese diskoers, Metahistory: The historical imagination in Nineteenth-Centruy Europe, lei Hayden White ${ }^{19}$ die narrativistiese benadering tot die historiografie in en toon hy aan hoe die groot geskiedskrywers van die negentiende eeu (Michelet, Ranke, Tocqueville, Burckhardt) van tradisionele literêre vorms soos die komedie, die satire, die tragedie en die romantiese verhaal gebruik gemaak het om geskiedenis as verhaal, as storie, te vertel. White tipeer die historiografie, soos die roman, as 'n talige konstruk, 'n verbale diskoers, 'n narratief soos ander narratiewe, wat van poëtiese middele soos ironie, metonimie en metafoor gebruik maak om 'n werklikheid te (her)skep. In haar werk Writing history as a prophet toon Wesseling aan dat sowel die roman as die dissipline geskiedskrywing as sodanig, radikale veranderinge begin ondergaan het van die jare twintig van die twintigste eeu. Waar die roman sig wegkeer van die oortuiging dat dit moontlik is om op objektiewe wyse, van buite af, die werklikheid te beskryf, en hom begin besig hou met die binnewêreld, die bewussyn van sy karakters, "contributors to the philosophy of history began to question the impartial and objectivist stance of professional historicist historiography." 20

\footnotetext{
18 D. van Zyl, Salomo syn oude goudfelde. Op die spoor van die retorika in die Afrikaanse romankunde (D.Litt-proefskrif, Universiteit van Suid-Afrika, 1995), p. 96.

19 H. White, Metahistory: The historical imagination in nineteenth-century Europe (Baltimore, 1973).

20 E. Wesseling, Writing history as a prophet (1991), p. 70.
} 
Die invloed van White op die uitgebreide akademiese diskoers wat vandag aangaande die wisselwerking tussen geskiedskrywing en letterkunde bestaan, kan nie oorskat word nie. Van die belangrike nuwe sienswyses wat inslag vind, is dat, as die geskiedskrywing ' $n$ talige diskoers is soos ander talige diskoerse en nie noodwendig op groter feitelikheid kan aanspraak maak as die letterkunde nie, die skeidslyn tussen geskiedskrywing en letterkunde dus vervaag. "History is best viewed epistemologically as a form of literature producing knowledge as much by its aesthetic or narrative structure as by any other criteria." ${ }^{21}$ Hierdie bewuswees van geskiedskrywing as nog 'n vorm van verhaalgewing, word veral deur postmoderne skrywers (vergelyk byvoorbeeld die roman Op soek na generaal Mannetjies Mentz ${ }^{22}$ hier) op talle wyses uitgebuit, sodat die grense tussen historiografie en fiksie dikwels nie bloot nie meer getrek word nie, maar die spanning tussen feit en verdigsel skering en inslag van die narratief vorm..$^{23}$

Belangrik vir die onderhawige betoog is nogtans dat die leser van die populêre historiese roman die (tradisionele) verskille tussen geskiedskrywing en fiksie steeds as geldig beskou, hoofsaaklik omdat die vormgewing van die twee tipes tekste betreklik drasties verskil. Ondersoektegnieke, verwysing na bronne en algemene doelstelling - die fiktiewe verhaal of plot, die lewe van gewone mense, wat sentraal staan in die populêre roman teenoor die poging om 'n greep te kry op historiese gebeure in geskiedskrywing - bly belangrike verskilpunte tussen die twee maniere om met die verlede om te gaan. Populêre historiese fiksie word op die oog af nog steeds taamlik onproblematies afgegrens van dokumentêre geskiedskrywing. Die moderne leser van 'n roman soos Vuur op die horsion verkeer vir geen oomblik onder die indruk dat hy/ sy 'n "geskiedenisboek" ter hand het nie. Dit is onder meer die geval omdat in die genoemde roman nie sprake is van die selfreflekterende besinning oor die optekening van die geskiedenis wat so deel is van die postmodernistiese historiese roman nie. Daar word geen metafiksionele kommentaar gelewer op dié spesifieke weergawe van die gebeure nie en die roman word baie soos 'n liefdes- en/of avontuurverhaal gelees.

Met die aanvaarding van 'n onbetwiste verband tussen historiografie en romansiering, bly dit nietemin so dat vir die doel van hierdie artikel op twee belangrike onderskeidende kenmerke van historiese fiksie gewys kan word. Aan die een kant verskyn fiktiewe karakters (naas figure wat werklik geleef het) wat in 'n historiese

\footnotetext{
A. Munslow, Deconstructing history (London, 1998), p. 5.

C. Coetzee, Op soek na generaal Mannetjies Mentz (Kaapstad, 1998).

L. Hutcheon se A poetics of Postmodern history, theory, fiction (New York, 1988) fokus op die postmodernistiese metafiksionele aspekte van die laat-twintigste-eeuse historiese roman.
} 
roman aangetref word en aan die ander kant is die hele vormgewing van die teks. Naas narratologiese tegnieke soos die bewuste hantering van die verhaalstruktuur en tydsverloop, fokalisasie, vertelperspektief, tydruimtelike plasing en karakterisering, is ook die wyse waarop met bronne in die aanbieding en voorhou van die teks omgegaan word van belang wanneer veral na verskille tussen historiografie en fiksie gekyk word.

Die onderskeid tussen die skrywer van 'n teks en die verteller binne die teks belig 'n verdere verskil tussen geskiedskrywing en fiksie. Onder "skrywer" ("outeur") word verstaan "die instansie wat die (...) werk (...) tot stand gebring het". ${ }^{24}$ Dit is dié skrywer wat bepaal watter soort storie vertel word asook wat die aard van die verteller (bv. betroubaar of nie) in die epiese werk sal wees. Onderskeibaar van hierdie organiserende instansie is die verteller in 'n roman die bemiddelende instansie waardeur die gebeure as 'n verhaal aan die leser voorgehou word. ${ }^{25}$ Die onderskeid tussen skrywer en verteller is nie van kardinale belang by dokumentêre geskiedskrywing nie - hierteenoor is dit 'n onderskeid waarsonder die historiese roman nie benader kan word nie. Die grootste verskil is waarskynlik die groter mate van vryheid wat die skrywer van 'n historiese roman aan sy verteller gee - hiervan is die roman van Christoffel Coetzee, Op soek na generaal Mannetjies Mentz, 'n goeie voorbeeld. Die verteller kan met die sogenaamde feite na goeddunke handel. Die skrywer van 'n geskiedkundige weergawe van dit wat gebeur het, geniet aansienlik minder vryhede en die werk word aan 'n ander stel maatstawwe as literêre oorwegings getoets.

Uit die voorafgaande uiteensetting kan afgelei word dat een van die gronde waarop 'n genre soos die historiese roman van ander romans onderskei en afgegrens kan word, op die verhouding tussen geskiedkundige feit en verdigsel, die balans tussen akkuraatheid en fiksie, waarheidsgetrouheid en illusie berus.

\section{Brongebruik en -aanduiding in die historiese roman}

Die leser van ' $n$ historiese roman het tegelykertyd twee verwagtings. Eerstens bestaan die vermoede of verwagting dat wat gelees gaan word minstens op 'n relatief noukeurige herskepping van historiese feite gegrond sal wees. Vergelyk die volgende gevolgtrekking oor die outentisiteit van gebeure in Vuur op die horison: "Die historisiteit van die oorlogsgebeure en die figure wat as't ware uit die geskiedenisboeke in die blaaie van die roman ingestap kom, bring mee dat feit en fiksie op 'n boeiende

24 T.T. Cloete (red.), Literêre terme en teorieë (1992), p. 359. 
manier vermeng word." ${ }^{26}$ Terselfdertyd weet die leser ook dat hy/sy met fiksie te doen het en word die vermoë ingespan waarsonder geen roman ter hand geneem kan word nie, te wete daardie gewilligheid om vir die duur van die lees van die roman bereid te wees om alles te glo wat daarin geskryf is. Om die leser by te staan in sy of haar "willing suspension of disbelief", beplan die skrywer van 'n historiese roman fyn aan die skepping van die romanwêreld en maak hy gebruik van 'n aantal tegnieke wat dit oorwegend ten doel het om die leser oor te haal om te glo dat sy 'n betroubare weergawe lees van dit wat moontlik werklik kon gebeur het.

Dit is in die (so noukeurig as moontlik) optekening van die verlede waar geskiedskrywing en fiksie mekaar ontmoet. By dokumentêre geskiedskrywing is een van die aanvaarde konvensies die gebruikmaking van so veel as moontlik betroubare dokumente en hiermee saam ook die noukeurige aanduiding en optekening van bronne. Dit is juis hierdie konvensie wat soms deur die skrywer van 'n historiese roman gebruik word om die grens tussen feit en fiksie af te breek of te laat vervaag. Een van die romans wat hierbo genoem is, S.J. du Toit se roman Di Koningin fan Skeba, of Salomo syn oue goudfelde in Sambesia, ${ }^{27}$ kan as voorbeeld dien.

In hierdie Historise roman, met prente probeer die verteller met allerlei tegnieke om die waarheidsillusie so min as moontlik te versteur. Hy klee sy verhaal in as die verslag van 'n reisgeselskap se tog na die Zimbabweruïnes. Die geselskap ontdek ou boekrolle wat die verhaal van die ryk van Skeba vertel en hierdie boekrolle word as primêre bronne aangebied. Die verteller verwys ook na 'n bestaande bron oor ou Egipte en gee sketse van die perkamentrol om die geloofwaardigheid van sy verhaal te versterk. Du Toit bevind hom met hierdie "conventional deceit of the found manuscript" ${ }^{28}$ in die geselskap van ander skrywers van historiese fiksie, soos Sir Walter Scott. Ander tegnieke wat deur Du Toit gebruik word, is die gebruik van foto's ("'n sterk oorredingsmiddel" volgens Van $\mathrm{Zyl}^{29}$ ) en sogenaamde ooggetuieverslae. Die gevolg van dié doelbewuste skep van 'n waarheidsillusie deur Du Toit was dat party tydgenootlike lesers die roman as 'n ware verslag beskou het: “. . . toenmalige lesers was meegesleur en beslis tot op 'n sekere hoogte onder die indruk dat die roman 'waar' kon wees." 30

In Van Rooyen se roman Vuur op die horison poog die verteller nêrens om met dergelike verteltegnieke die leser oor te haal om in die waarheid van die romangebeure

\footnotetext{
L.S. Venter, Belangrike bydrae tot die historiese roman, Beeld, 2000-07-03.

S.J.du Toit, Di Koningin van Skeba (faksimilee-uitgawe), (Kaapstad, 1998).

E. Wesseling, Writing history as a a prophet (1991), p. 37.

S.J.du Toit, Di Koningin van Skeba (1998), p. 15.

D. van Zyl, Salomo syn oude goudfelde (1995), p. 153.
} 
te glo nie. Hierdie artikel steun nogtans op die aanname dat die skryfster gebruik gemaak het van 'n moontlik wyd uiteenlopende reeks bronne waarop vir die konstituering van die romanwerklikheid gesteun word.

In die jongste jare het dit tradisie geword dat skrywers van historiese romans soms bronnelyste verskaf, maar geen vaste konvensie bestaan blykbaar wat gevolg word nie. In historiese romans oor die Anglo-Boereoorlog deur Ferreira ${ }^{31}$ en Baker ${ }^{32}$ verskyn uitgebreide en noukeurige bronnelyste aan die einde, maar sodanige inligting ontbreek byvoorbeeld in Eilande van Sleigh. ${ }^{33}$

Van Rooyen het haar onderwerp (die jare onmiddellik voor, tydens en na die AngloBoereoorlog) duidelik deeglik nagevors. ${ }^{34}$ Omdat sy geen verwysings na enige bronne verskaf nie, is dit moeilik om na te gaan op watter wyse tekste wel in die roman geïntegreer is. Dat een van die bronne waarvan sy wel gebruik gemaak het, die reeds genoemde roman van Pirow is, sal verderaan deeglik blyk.

Daar is reeds genoem dat in party postmoderne historiese romans 'n doelbewuste spel aangetref word waarin die waarheidsgetrouheid en outentisiteit van brontekste op 'n bestudeerde, selfbewuste manier bevraagteken en uitgedaag word en die grense tussen geskiedskrywing en fiksie al vaer getrek word. Die vraag is of die roman Vuur op die horison ook as postmodern beskou kan word. So 'n kensketsing mag 'n leser se oordeel oor brongebruik in hierdie teks beïnvloed. In Vuur op die horison is nie werklik blyke van 'n bewuswees van die akademiese gesprek rakende historiografie en narratief nie. Die roman staan volledig binne die tradisie van die realistiese, populêre roman. Daar is geen aanduiding in die roman dat Van Rooyen skeppend met intertekste te werk gegaan het nie en dit is ook te betwyfel of Mlungu Mungoma deur lesers as interteks herken sou word, sodat die spel waardeer kan word. As gevolg van hierdie gebrek aan selfbewustheid by die outeur, ${ }^{35}$ kies hierdie leser saam met talle ander dan ook om die roman te beskou as 'n tradisionele historiese roman wat 'n verbygegane tyd so lewensgetrou as moontlik wil herskep. Sonder die sanksie wat 'n etiket soos postmodernisme aan die "speel met die waarheid" verleen, word die gebruik van tekste sonder erkenning as bronne van inspirasie in die roman wel problematies en dit is op hierdie aspek wat in die slotgedeelte van die artikel gekonsentreer word.

\footnotetext{
31 J. Ferreira, Babette (Johannesburg, 1995).

32 E. Baker, Groot duiwels dood (Kaapstad, 1998).

33 D. Sleigh, Eilande (Kaapstad, 2002).

34 Vergelyk byvoorbeeld die volgende resensies en onderhoude: D. van Zyl, Engela van Rooyen se honderdste roman, Rapport, 2000-07-16; H. van Vuuren, 'n Baie dik epos, http://www.oulitnet.co.za/ seminaar/vuur,asp., 2008-10-07; S. Nieuwoudt, Sagte potlood raas hard in nag, Beeld, 2008-06-14.

35 Ook op die vlak van vormgewing sou hierdie leser nie die roman as postmodern tipeer nie.
} 


\section{'n Vergelyking tussen Vuur op die horison en Mlungu Mungoma}

In sowel Vuur op die horison as Mlungu Mungoma kan die skrywers se strewe om die leser van die geloofwaardigheid van die verhaalgegewe aan die een kant te oortuig, en die leser van historiese romans se eie waardering vir noukeurige navorsing aan die ander kant herken word. Met die wyse waarop die skrywers van hierdie twee romans die geloofwaardigheid van hulle verhale versterk, is interessante parallelle te trek.

Sodra ' $n$ teks getipeer word as behorende tot 'n bepaalde genre word spesifieke verwagtings by die leser geskep. Met Vuur op die horison is die verwagting betreklik ondubbelsinnig - boekresensies het die roman al as 'n historiese roman aangekondig en die leser verwag dat hy/sy 'n roman te lese gaan kry wat min of meer in die tydperk voor, tydens en na Anglo-Boereoorlog afspeel. As gevolg van die onbekendheid van die Pirowteks, is hier egter nie sprake van 'n soortgelyke verwagting nie. Trouens, die subtitel (of Die blanke waarsêer) laat die klem op iets heeltemal anders val. Die verteller in die inleiding tot die Pirow-roman maak dit duidelik dat dit hier handel oor die wêreld van onsienlike dinge, tokkelossies, gebeure wat "ons in oud-Germaanse sagas" vind. Kennis van die ander werke van Pirow kan die verwagting versterk dat ons stories en legendes van die "Bantoe se spookwêreld" sal aantref. Tog speel die grootste deel van die roman tydens die Anglo-Boereoorlog af, en kan dit om hierdie rede ook as 'n historiese roman beskou word.

In Vuur op die horison beroep die skryfster haar op die leser se bereidwilligheid om die romangebeure as outentiek te aanvaar en om voorts te aanvaar dat die skryfster haar huiswerk gedoen het en haar so na as moontlik aan die feite van die oorlog wou hou. In Mlungu Mungoma doen die verteller baie meer om die leser te oortuig van die waarheid van dit wat gelees word. Pirow plaas sy roman in die konteks van die Laeveld, "die land van stories en legendes". Hy gebruik 'n tegniek wat goed aan ons bekend is om die geloofwaardigheid van sy vertelling te verhoog. Om 'n voorbeeld te noem: in sy spookstories stel Langenhoven die een na die ander "geloofwaardige" verteller aan die woord: 'n volksraadslid, 'n inspekteur, 'n professor, ensovoorts. In navolging van dié tegniek sê die verteller in Mlungu Mungoma dat hy die hele verhaal van "die Blanke Waarsêer" by 'n rustende magistraat gehoor het en meld dan dat die verhaal deur heelwat geskiedkundige feite gestaaf word. Hierna tree die inleidende verteller uit en laat dan die verhaal oor aan die eintlike verteller, die landdros ${ }^{36}$ wat

36 Pirow gebruik sowel die term "magistraat" Mlungu Mungoma (p. 2) as "landdros" Mlungu Mungoma (p. 6). Die outeur volg sy gebruik hier na. 
op sy beurt baie moeite doen om die bronne van sy verhaal aan die leser bekend te maak. ${ }^{37}$

Die landdros noem drie bronne: Humo, afstammeling van die priesterkonings van Monomotapa, Mawewe, 'n leerling van Humo en laastens 'n "gedegenereerde" witman van die "hoogste Europese adel", Tagati, die man wat van die duiwel besete was. ${ }^{38}$ Die vertellings van Mawewe word aangebied in die vorm van 'n onderhoud wat weer eens die indruk van outentisiteit by die leser moet versterk. Daar is selfs sprake van 'n dokument wat die landdros later self in die Staatsargief te siene kry en wat onbetwisbaar dui op die historiese bestaan van Orn Olen, die hoofpersonasie en die waarseêr van die titel. ${ }^{39}$

Met die noukeurige manier waarop die bronne aangedui word by wie die landdros in Mlungu Mungoma die feite oor die latere lewe van Orn Olen gekry het, kan 'n eerste verskil met die roman van Van Rooyen aangetoon word. Nêrens in Vuur op die horison word die leser direk deur die verteller op die noukeurigheid of lewensgetrouheid of "waarheid" van die "feite" gewys nie. Vir die leser wat op 'n speurtog wil vertrek na die bronne van dié roman, kan allerlei verrassings op pad wees. So is dit ' $n$ verrassing wanneer die leser uitvind dat een van die bronne waarvan Van Rooyen onmiskenbaar gebruik gemaak het, nie net as bron vir die inkleding van die historiese agtergrond is nie, maar as direkte inspirasie vir een van die kleurryke karakters in die roman, einste Mlungu Mungoma van Pirow dien.

Tensy die leser sonder twyfel anders weet, is die karakters in 'n historiese roman oorwegend fiktief. Ter wille van geloofwaardigheid maak historiese figure natuurlik hulle verskyning, maar hulle word woorde in die mond en gedagte gelê wat bes moontlik die skrywer se eie verbeeldingswerk is. 'n Vergelyking van die twee romans is onafwendbaar wanneer die fiktiewe karakters ${ }^{40}$ Swart Erik en Orn Olen in Mlungu

37 Tussen die twee vertelstemme is bykans geen stylverskil nie; die stem van die landdros klink trouens baie soos ander vertelstemme in die werke van Pirow. Daar is passasies in Mlungu Mungoma wat feitlik identies in Sikororo aangetref word. Vergelyk onder baie ander: "Hierdie wêreld is nie so hoog soos Natal se Mont-aux-Sources nie, maar dit is baie wilder" (Mlungu Mungoma, p. 133); "Die Drakensberge in hierdie gebied is nie so hoog soos byvoorbeeld dié van die Mont-aux-Sources nie, maar hulle is baie wilder" (Sikororo, p. 6); "In daardie dieptes het die diere merkwaardige groot oë en daar is van hulle wat jy in geen natuurkundeboek sal kry nie (Mlungu Mungoma, p. 133); "In daardie dieptes is die diere ongewoon groot en het hulle merkwaardige wye oë. Daar is van hulle wat jy in geen natuurkundeboek sal kry nie" (Sikororo, p. 7).

38 O. Pirow, Mlungu Mungoma (1949), p. 87.

39 O. Pirow, Mlungu Mungoma (1949), p. 7.

40 Dat die karakters waaroor dit hier gaan wel fiktief is, is 'n afleiding wat gemaak word. C. de Jong in Skandinawiërs in die Tweede Anglo-Boereoorlog (Amsterdam, 1983), meld nóg die name van Swart Erik of Orn Olen nóg dié van Olav Ostfedt as lede van die Skandinawiese korps. Veldkornet Flygare, wat wel in Mlungu Mungoma as karakter verskyn, is daarenteen nie 'n fiktiewe figuur nie. 
Mungoma van nader beskou word en die manier waarop dié twee karakters in die figuur van Olav Ostfedt in Vuur op die horison weerklank vind.

Soos reeds aangedui is, het Pirow baie moeite gedoen om die leser te oortuig van die waarheidsgetrouheid van sy verhaal. Daarteenoor aanvaar die leser van Vuur op die horison waarskynlik bloot dat dit 'n fiktiewe teks en fiktiewe karakters is. Waar Van Rooyen een karakter, Olav Ostfedt "geskep" het, lees ons in Mlungu Mungoma van 'n vader en seun wat albei as lede van die Skandinawiese korps aan die Boerekant in die oorlog geveg het. Die karakter Olav Ostfedt in Vuur op die horison kan as 'n samevoeging van die karakters Swart Erik Olen en sy seun Orn beskou word. Onmiskenbare ooreenkomste bestaan tussen die karakters Olav Ostfedt en sowel Swart Erik as sy seun Orn Olen. Soos Swart Erik, het Olav ook 'n swart baard. Swart Erik se vrou, Orn se moeder, word deur 'n fratsgolf van 'n Noorweegse seilskip oorboord gespoel; ${ }^{41}$ in Vuur op die horison sterf Olav se ma op dieselfde manier. ${ }^{42}$ Sowel Swart Erik as Olav werk as yster- en goudsmid en word deur hulle besondere krag gekenmerk. Swart Erik en Olav vertel altwee Noorse sages om die blaasbalk in hulle smidswinkels. Orn Olen kan die toekoms vooraf sien-Olav besit ook die vermoë. By Mafeking én by Magersfontein skree Swart Erik die Viking-oorlogskreet "Tur aie" en spring oor die klipskans; ${ }^{43}$ by Magersfontein skree Olav die Viking-oorlogskreet "Tur aie" en spring oor die klipmuur. ${ }^{44}$ Albei karakters sterf by Magersfontein nadat hulle deur bajonette deurboor is.

Swart Erik se "naturellenaam" is "Isimbi"; Modjaa, die "veldgees" in Vuur op die horison noem Olav "Isimbi”. Olav leer by die Sjangaans sy lewensfilosofie; Orn Olen kom onder die invloed van 'n Sjangaantoordokter, Humo. Olav noem sy huis Walhalla; in Mlungu Mungoma staan Orn Olen en Naas Ferreira, sy vriend, se verblyfplek as Valhalla bekend.

Die ooreenkoms tussen die karakters Olav Ostfedt en Swart Erik / Orn Olen is nie slegs op verhaalvlak te bespeur nie. Sekere passasies in Vuur op die horison kan feitlik woordeliks in Mlungu Mungoma teruggevind word:

Uit Vuur op die horison

Olav hang "Priester Jan" met die agterkant van sy rewolwerband aan 'n boom op. "Weens die druk van die rewolwerband op sy maag is hy naastenby flou en is sy mond ook 'n slag stil." 45

41 O. Pirow, Mlungu Mungoma (1949), p. 11.

42 E. van Rooyen, Vuur op die horison (2000), p. 47.

43 O. Pirow, Mlungu Mungoma (1949), p. 18.

44 E. van Rooyen, Vuur op die horison (2000), p. 394.

45 E. van Rooyen, Vuur op die horison (2000), pp. 362-363. 


\section{Uit Mlungu Mungoma}

Swart Erik hang 'n karakter met die naam Swart Jan met sy rewolwerband op in die trein. Ons lees: “ ....(Swart Jan is) met die vreeslike druk op sy maag, gereed om flou te val" teen die tyd dat sy mense hom afhaal. ${ }^{46}$

Die ironie bly nie uitgesluit nie, byvoorbeeld waar Olav beskryf word as "'n figuur uit en van sy Noorse sprokies". Die ingeligte leser kan byvoeg: en ook uit 'n (onbekende) Afrikaanse boek! In Mlungu Mungoma word Orn naamlik soos volg beskryf: "Maar daardie dag, toe hy sy kop lig en die wêreld waterpas in die oë kyk, was hy soos 'n jong blonde Viking uit 'n Noorse saga (sic). ${ }^{977}$ Olav dood 'n leeu deur hom met 'n byl te gooi; Orn dood 'n verwoede buffelbul ook so.

Die ooreenkomste is so talryk dat geen twyfel kan bestaan dat Van Rooyen in 'n baie groot mate geput het uit die karakters van Swart Erik en Orn om haar karakter Olav te skep nie, maar groot verskille tussen die figure Orn Olen en Olav Ostfedt kom eweneens voor. Na Magersfontein beland Orn in die Laeveld en kom onder die invloed van die Sjangaantoordokter Humo. Uiteindelik het hy "oor die brug gegly van die Noorse mitologie na die bygelowe van die Sjangaans" 48 en hy sterf uiteindelik 'n tragiese dood. Die "Lucifer-gestalte" van die Sjangaanpriester Humo, die laaste opvolger van die priesterkonings van Monomotapa, is 'n sterk teenwoordigheid in Pirow se roman. Ooreenkomste is merkbaar tussen die Sjangaantoordokter Humo en die karakter Modjaa in Vuur op die horison, hoewel laasgenoemde figuur nie naastenby so 'n sinistere figuur as Humo is nie - hy is eerder 'n "mistieke veldgees". ${ }^{49}$

Olav Ostfedt is nie een van die sentrale karakters in die roman nie en die invloed van Mlungu Mungoma, is in die lig van die wye epiese inslag van die roman, op die roman as geheel nie baie groot nie. Buiten dat die karakters Swart Erik en Orn Olen gebruik is om die figuur van Olav Ostfedt te skep, het hierdie leser nie enige ander tekens bespeur van 'n kreatiewe omgaan met die Pirow-teks nie.

\section{Ten slotte}

In hierdie artikel is gepoog om die aard van die historiese roman baie kortliks te tipeer. Hoewel in sowel in die eietydse vakliteratuur as die postmoderne romankuns 'n lewendige diskoers oor die ingewikkelde verhouding tussen historiografie en letterkunde plaasvind, word hierdie verhouding nie in die sogenaamde populêre

\footnotetext{
46 O. Pirow, Mlungu Mungoma (1949), p. 31.

47 O. Pirow, Mlungu Mungoma (1949), p. 25.

48 O. Pirow, Mlungu Mungoma (1949), p. 3.

49 E. van Rooyen, Vuur op die horison (2000), p. 18.
} 
historiese roman geproblematiseer nie. Klem is hoofsaaklik gelê op een tegniek waarvan die romanskrywer hom kan bedien om sy fiktiewe werklikheid geloofwaardiger te maak, te wete die verwysing na bronne, dokumente, foto's en dergelike meer. Die wyse waarop brongebruik in een spesifieke roman gehanteer word, is onder die loep geneem en die gebrek aan erkenning deur die skryfster van die roman oor die gebruik van dié inspirasiebron is aangeteken. Die verhouding tussen teks en bronteks(te) en die manier waarop verantwoording gedoen word van die mate waartoe op ander tekste in die skepping van 'n romanwêreld gesteun word, bly 'n kontroversiële en kontensieuse aspek van die letterkunde. In die klein (Suid-)Afrikaanse letterkundige wêreld het opstootjies al voorgekom en skandale rondom die gebruikmaking (met of sonder vermelding) van reeds geskrewe tekste. Binne die genre van die populêre historiese roman is dit opvallend hoe anders Ferreira (om slegs een voorbeeld te noem) as Van Rooyen omgaan met die verwysing na bronne wat geraadpleeg is. Ter wille van die meer ingeligte leser (en seker ook ter beskerming van die skrywer teen moontlike plagiaataanklagte) sou gesien wou word en dat met groter noukeurigheid verslag gedoen word van bronne wat gebruik is. As 'n konvensie wel besig is om te ontwikkel waar skrywers (ook skrywers van populêre romans) hulle skatpligtigheid aan invloede buite die teks op geen onduidelike manier nie, erken, moet dit verwelkom word. 